\title{
Urinary Mutagenicity in Chemical Laboratory Workers Exposed to Solvents
}

\author{
Soraya D. Varella, Raquel A. Rampazo and Eliana A. Varanda \\ Department of Biological Sciences, Faculty of Pharmaceutical Sciences of Araraquara, State University of São \\ Paulo (UNESP), Brazil
}

\begin{abstract}
Urinary Mutagenicity in Chemical Laboratory Workers Exposed to Solvents: Soraya D. VARELLA, et al. Department of Biological Sciences, Faculty of Pharmaceutical Sciences of Araraquara, State University of São Paulo (UNESP), BrazilSolvents represent an important group of environmental pollutants to which people are exposed daily in the workplace. The physico chemical properties of solvents may result in disturbances to cellular structures, including damage to DNA. However, the effects of mixtures of solvents are not well known. Mutations caused by environmental agents are related to cancer development and other degenerative diseases. The work in a research laboratory that uses several types of solvents is equally predisposed to these hazards. In this study, we evaluated the mutagenicity of urine from 29 subjects exposed occupationally to solvents in a chemistry research laboratory and 29 subjects without occupational exposure (controls). Urine samples were collected in polyethylene containers at the end of the work shift. For the concentration and extraction of urine samples the XAD-2 resin was used with acetone as an eluting agent. Several strains of Salmonella typhimurium (TA100, TA98, TA97a, TA1535, YG1024) should be used to assess mutagenic susceptibilities among workers exposed to organic solvents. Different doses of extract $(1.5 ; 3.0 ; 6.0$ and $12.0 \mathrm{~m} /$ equivalents of urine per plate) were tested on S. typhimurium strains TA100 and YG1024, with and without metabolic activation. The mutagenic activity, measured in Salmonella typhimurium YG1024 with S9 mix, was significantly greater in urine from workers than from controls $(p \leq 0.05)$. These results indicate the relevance of using biomarkers to assess the risk of
\end{abstract}

Received Nov 9, 2007; Accepted Jul 11, 2008

Published online in J-STAGE Aug 19, 2008

Correspondence to: E.A. Varanda, Department of Biological Sciences, Faculty of Pharmaceutical Sciences of Araraquara, State University of São Paulo (UNESP), Rodovia Araraquara-Jaú Km 1, 14801-902, Araraquara, São Paulo, Brazil

(e-mail:varandae@fcfar.unesp.br) occupational exposure to organic solvents. (J Occup Health 2008; 50: 415-422)

Key words: Urine mutagenicity, Genotoxic exposure, Solvents, Salmonella, Reversion assay

Solvents are an important group of environmental pollutants to which people are exposed every day at work. The physicochemical properties of solvents can cause disturbances to cellular structures, including damage to DNA. Ethanol damages membranes and leads to ion imbalances ${ }^{1)}$. Benzene is a volatile aromatic hydrocarbon solvent that is widely used in industry and also a ubiquitous environmental pollutant, being a component of cigarette smoke, gasoline, and automobile emissions ${ }^{2)}$. The chronic exposure of humans to low levels of benzene in the workplace has been associated with blood disorders, including aplastic anemia and leukemia ${ }^{3,4}$. Benzene metabolites bind covalently to proteins and DNA in biological systems such as cells or tissues, thereby inducing intracellular toxic effects, such as inhibition of cell replication or carcinogenesis ${ }^{5)}$. Halogenated hydrocarbons are frequently found in both industry and the home. For example dichloromethane is used as a lipophilic solvent in the rubber and textile industries, and it is also used as a lacquer remover and in hair sprays ${ }^{6}$. Chronic exposure to n-hexane is known to induce peripheral neuropathy in humans and laboratory animals ${ }^{7}$.

Inhalation of volatile organic compounds continues to pose a health concern in industrialized countries, due to high volumes of production and release into the atmosphere and human clinical trials frequently report neurobehavioral deficits from exposure in the workplace ${ }^{8}$. On the other hand, several reports of in vitro exposures have given inconsistent results in the literature. DeFlora et al. ${ }^{9)}$ found a very weak positive effect of ethanol in a DNA repair test with $E$. coli, but no effect in the Ames test with strains TA1535, TA1537, TA1538, TA97, TA98 and TA100, with the exception of TA102 which gave a weak reproducible effect. 
Urine mutagenicity measures the extent of recent exposure to mutagens and it has been used in biomonitoring studies of populations exposed to environmental and/or workplace-generated complex mixtures ${ }^{10)}$. Although urine mutagenicity is nonspecific in that it does not identify the various mutagens in urine, it has the advantage of integrating the effects of all the mutagenic compounds in urine and estimating their sum, without the need to carry out a separate analysis for each mutagenic compound ${ }^{11)}$.

Increased urinary mutagenicity has been demonstrated among people who smoke cigarettes ${ }^{12)}$, are exposed to mutagenic drugs ${ }^{13)}$, eat fried meats ${ }^{14)}$, and workers exposed to aromatic amines as in the rubber ${ }^{15)}$, textiles ${ }^{16)}$, ink and pharmaceutical industries ${ }^{17}$.

In the current study, we have measured the mutagenic activity of urine samples from chemistry laboratory workers occupationally exposed to organic solvents (such as n-hexane, dichloromethane, acetone, benzene, ethanol and toluene). Mutagenic activity was assayed with the Salmonella/microsome assay, using strains TA100 and YG1024.

The hisG46 marker in strain TA100 results from the substitution of a leucine (GAG/CTC) by a proline (GGG/ CCC). This mutation reverts to the wild-type state through mutagens that cause base-pair substitution mutations primarily at one of the GC pairs ${ }^{18)}$. The YG1024 test strain is a derivative of $S$. typhimurium TA98 (detect frameshift mutagens) with high activities of classical $O$-acetyltransferase, and detects more efficiently the mutagenicity of aromatic nitro, amino and hydroxylamino compounds ${ }^{19,20)}$.

\section{Materials and Methods}

\section{Chemicals}

Dimethylsulfoxide (DMSO), nicotinamide adenine dinucleotide phosphate sodium salt, D-glucose-6phosphate disodium salt, L-histidine monohydrate, sodium azide (AZS) 2-anthramine (2-AA), 4 nitro- $O$ phenylenediamine (NPD), and D-biotin were purchased from Sigma (St. Louis, MO). Nutrient Broth No. 2 was purchased from Oxoid (Basingstore, Hampshire, U.K.) and Bacto Agar from Difco (Detroit, MI). All other reagents used to prepare buffers and perform the assays were from Merck (Whitehouse Station, NJ) and Sigma.

\section{Subjects and sample collection}

The experimental protocol was approved by the Ethics Committee of the School of Pharmaceutical SciencesUNESP-São Paulo State University at Araraquara, SP, Brazil and all participants gave their informed consent. The study was carried out with a test group consisting of 29 healthy non-smokers, whose work, study or teaching duties involved daily activity in the organic chemistry research laboratories of the Araraquara Institute of
Table 1. Age, gender and number of volunteers for the control and exposed groups

\begin{tabular}{lcc}
\hline & Control group & Exposed group \\
\hline $\begin{array}{l}\text { Number of volunteers } \\
\text { Age }\end{array}$ & 29 & 29 \\
$\quad$ Mean \pm SD & $28 \pm 9$ & $29.3 \pm 7.7$ \\
$\quad$ Range & $19-49$ & $19-54$ \\
Gender & & \\
Female & 19 & 19 \\
Male & 10 & 10 \\
\hline
\end{tabular}

Chemistry-UNESP at Araraquara (Brazil), and a control group of 29 non-smoking employees and students, all involved in types of work that did not expose them to solvents, paired for sex and age with the test subjects. Table 1 shows the subject descriptions. In their work, the test group has exposures to diverse solvents, including: ethyl acetate, acetonitrile, methanol, acetone, ethanol, hexane, benzene and dichloromethane. All of the subjects answered a detailed questionnaire including general information about their personal and occupational history and health. Those who were under medication or ingested alcohol daily were excluded. The individuals selected for the study were oriented about not taking alcohol and not eating barbecued meat or fried food for one day before the collection of the urine sample. They were also instructed to collect the urine sample ( $24 \mathrm{~h}$ urine sample) on a single day, when high exposure ( $8 \mathrm{~h}$ of exposure) to organic solvents occurred. Protection equipment, mask, gloves and an extraction hood are used for the handling of the most dangerous solvents, such as acetonitrile, but for most of the solvents, the laboratory workers did not wear masks or work at the hood. Experiments are done on the bench, facilitating the dispersion of the solvents throughout the laboratory. In the exposed group, 56.6\% had a history of exposure from 1 to $5 \mathrm{yr}, 23.3 \%$ from $6-$ $10 \mathrm{yr}$ and $20 \%$ had worked more than $20 \mathrm{yr}$ with organic solvents. Ages varied between 19 and 54 yr. To exclude the possibility of interference of individual diets in the urine mutagenicity, personal data were collected in the questionnaire about eating habits; $6.6 \%$ of the subjects did not eat vegetables, $26.7 \%$ never drank alcohol, $45 \%$ occasionally took drink with alcoholic content and $28.3 \%$ consumed 1 to 4 glasses of alcoholic drink a week. All volunteers were instructed to collect urine when they had not taken medicines.

Urine samples (around $800 \mathrm{ml}$ ) were collected in polyethylene containers at the end of the work shift, and stored at $-20^{\circ} \mathrm{C}$ until assay.

\section{Concentration and extraction of urine samples}

The urine sample was thawed and adjusted to $\mathrm{pH} 7.0$ 
with $\mathrm{NaOH}$. The sample was loaded on Amberlite XAD2 resin using the method developed by Yamasaki and Ames ${ }^{12)}$, and the absorbed materials were eluted with acetone using a flow rate of $2-3 \mathrm{ml} / \mathrm{min}$, regulated by means of a stopcock. Each of the eluted fractions was thoroughly mixed before the tubes were placed in a constant temperature heating block (Eppendorf® Concentrator 5301 ) at $40-45^{\circ} \mathrm{C}$ to evaporate the solvent. After complete drying, the solid residue was dissolved in $0.4 \mathrm{~m} l$ of DMSO per $100-\mathrm{m} l$ equivalent of urine extract.

\section{Mutagenicity test}

Mutagenicity was determined using the preincubation version of the Salmonella/microsome assay as described by Maron and Ames ${ }^{18)}$. The urine extracts were tested in Salmonella typhimurium strains TA100 (kindly provided by Dr. Bruce Ames, Children's Hospital Oakland Research Institute, Oakland CA,USA) and YG1024 (a gift from Dr. M. Watanabe, National Institute of Hygienic Sciences, Tokyo, Japan), with and without metabolic activation using Aroclor 1254-induced rat liver homogenate (S9). Frozen stocks of the tester strains were grown for 12-14 h in Oxoid Nutrient Broth No. 2. Extracts equivalent to $1.5,3.0,6.0$, and $12.0 \mathrm{~m} l$ of urine were added in DMSO to $100 \mu l$ of bacterial culture and $0.5 \mathrm{ml}$ phosphate buffer $\mathrm{pH} 7.4$ or $0.5 \mathrm{ml} 4 \% \mathrm{~S} 9$ mixture. After incubation for $20-30 \mathrm{~min}$ at $37^{\circ} \mathrm{C}, 2 \mathrm{ml}$ of top agar were added to the bacterial suspension and mixed. Then, the mixture was poured onto a minimal agar plate. The plates were incubated at $37^{\circ} \mathrm{C}$ for $48 \mathrm{~h}$ and the his+ revertant colonies were counted with an automatic counter (Synoptic Ltda, made in UK, Protocol model 60000). All experiments were performed in triplicate.

Positive controls were included in each experiment: 2-anthramine with S9 and sodium azide (for TA100) and 4-o-nitrophenylenediamine (for YG1024) without S9. XAD-2 extractions were performed on $100 \mathrm{~m} l$ samples of distilled water. The residues were dissolved in DMSO, and used as negative (solvent) controls.

The mutagenic index (MI) was calculated for each dose as the mean number of revertants per plate divided by the mean number of revertants per negative control plate. A sample was considered positive when the MI was equal to or greater than 2 for at least one of the tested doses and if it had a reproducible dose-response ${ }^{21)}$. Several authors have used this parameter in their works ${ }^{22-25}$. According to Mortelmans and Zeiger ${ }^{26)}$, in an important review of the Ames test a widely used approach is to analyze the results and to set a minimum fold increase, usually 2-3 folds, in revertants (over the solvent control) as a cut-off between mutagenic and nonmutagenic responses.

The highest MI is the highest among the different doses of urine.

The mean relative mutagenicity increase index was calculated: highest number of his+ revertants obtained with each sample of urine, minus the his+ revertants in the negative control, divided by the number of his+ revertants in the negative control.

\section{Statistical analyses}

The mutagenicity assays were analyzed statistically with the Salanal computer program (U.S. Environmental Protection Agency, Monitoring Systems Laboratory, Las Vegas, NV) adopting the Bernstein model ${ }^{27)}$. The slope of the linear portion of the dose-response curve calculated by the linear regression method as the number of revertants $/ \mathrm{m} l$ urine was named the mutagenic power (MP). Urinary mutagenicity in the control group was compared to that in the workers exposed to solvents with Student's $t$-test.

\section{Results}

We tested the mutagenicity of urine samples collected from solvent exposed workers and controls; both groups were made up only of nonsmokers. We found a significant difference $(p<0.05)$ between the mutagenic activity of the urine samples from the exposed workers and the controls in tests employing strain YG1024 with S9 mix.

Figures 1 and 2 show the revertants numbers/plate (M $\pm \mathrm{SD}$ ) obtained for the highest dose used.

The highest MI values detected for urines samples are given in Table 2. The highest MI values were generally detected in the urine samples of exposed workers that were assayed with Salmonella typhimurium YG1024 (+S9). Six samples (02E, 09E, 39E, 40E, 44E and 45E) from the exposed group showed positive mutagenic activity in the YG1024 strain with S9 mix and one of them was positive without S9 (54E).

The mutagenic potency of these seven samples from the exposed group, shown in Table 3, have mutagenic power (MP) values between 1.8 and 25.9. Only one control urine sample (04C) had mutagenic activity in TA100 and one (36C) in YG1024. These two samples from the control group showed MP values between 2.3 and 13.8 (Table 3). All of these mutagenic responses for control urine samples were detected in the absence of S9 activation. For assays conducted in YG1024 + S9, the mean highest MI for the exposed workers was significantly greater than the mean highest MI value for the controls $(p<0.05$; Table 2$)$ suggesting that in the urine of the exposed volunteers there was a larger amount of substances that can interact with DNA when compared with the volunteers of the control group. Also, for the assays conducted in YG1024 $+\mathrm{S} 9$, the mean relative mutagenicity increase index was higher in exposed workers'urine than in controls'urine. These results are shown abstractly in Fig. 3 (relative increase index in the number of his+ revertants). 
A
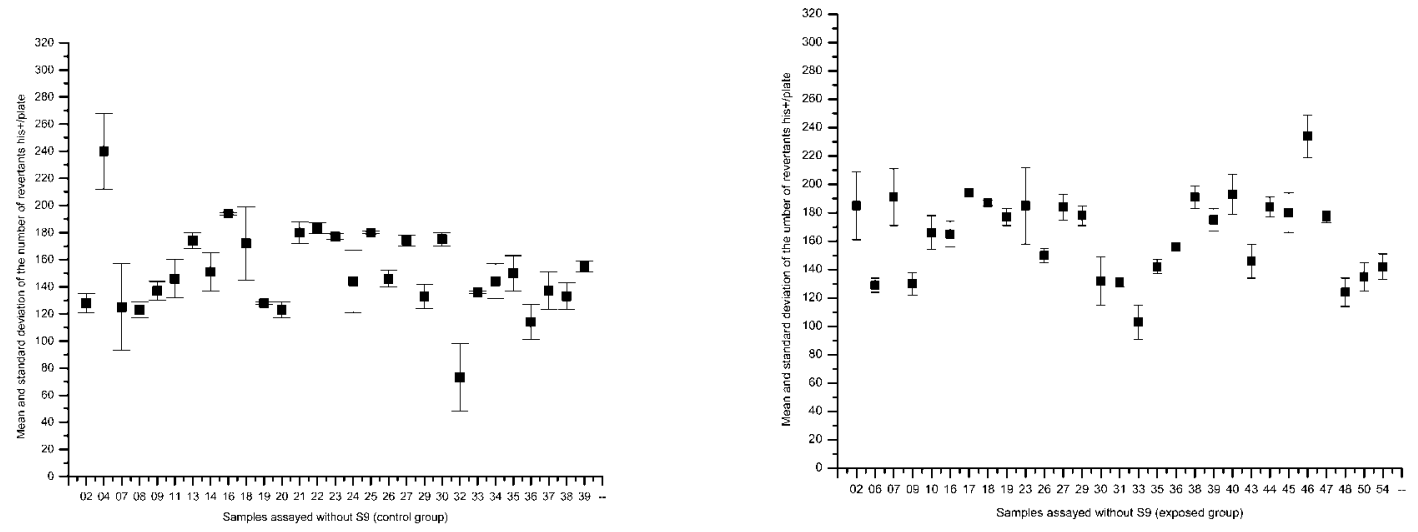

B
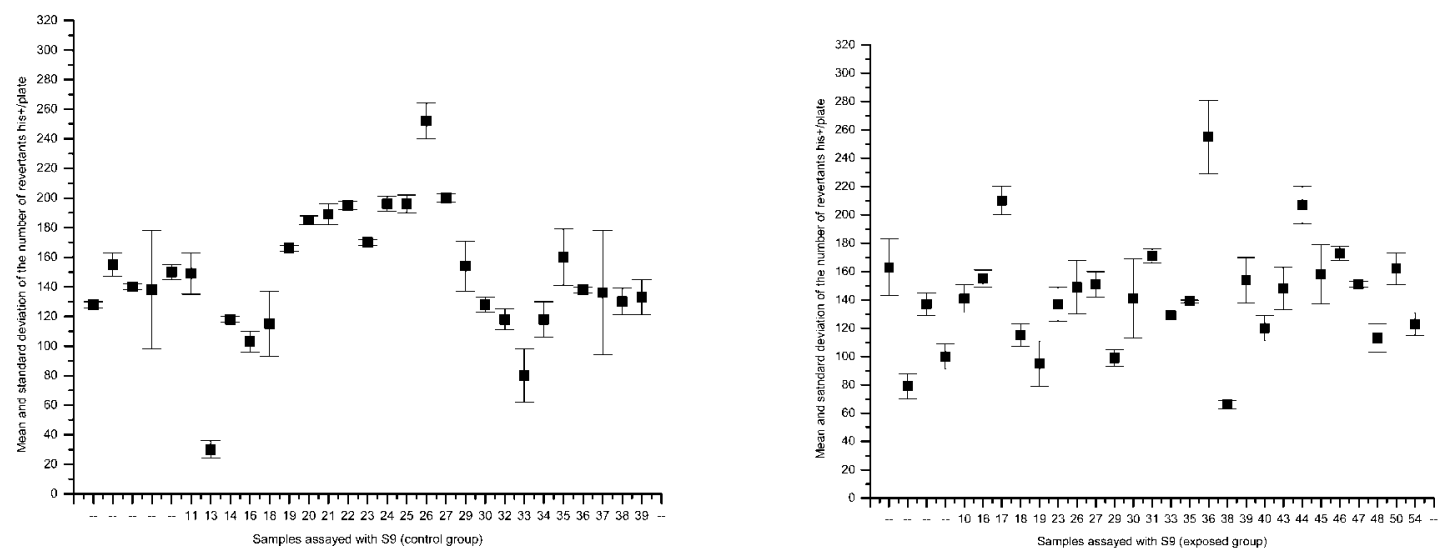

Fig. 1. Mean and standard deviation of the number of his+ revertants/plate for urine samples $(12.0 \mathrm{~m} l$ equivalent of urine) from individuals from the control and exposed groups in the Salmonella typhimurium TA100 strain, without (A) and with (B) metabolic activation.

\section{Discussion}

Urinary mutagenic activity has been used in occupational and epidemiological studies for decades as a cost effective, general biomarker of exposure to genotoxic compounds, e.g., occupational exposures in the rubber, coke oven, ink, pharmaceutical, and textile industries $^{28-30)}$.

The data from bacterial mutagenicity assays, particularly the Ames test, and the results of exposure to ethanol have generally been negative ${ }^{31-33)}$. However, the effects of organic solvents mixtures are not well known, but an elevated risk was considered to be a consequence of exposure to complex mixtures ${ }^{34)}$. Toluene is frequently cited as responsible for the results, but individually they are not or little genotoxic ${ }^{35)}$.

Another aspect often considered is that solvents properties would affect liver enzymes activities (and possibly those of the gut microflora) conceivably leading to the increased formation of mutagens derived from dietary constituents ${ }^{36)}$.

The results of this study demonstrated an increase of urinary mutagenic activity in workers exposed to solvents mixture. However, one control urine sample (36C) showed positive mutagenic activity in the absence of S9 activation, in the YG1024 strain. Interindividual variability in the urine mutagenicity responses seems to be the main disadvantage of this biomarker, and the differences may be explained by genetic, personal habits and lifestyle in addition to mutagenic pollutants in the environment ${ }^{37)}$.

The urine samples from the exposed group had a greater mean highest MI value and a greater mean relative mutagenicity increase index than the control group. The increase in mutagenicity, however, was limited to assays conducted with the O-acetyltransferase-overproducing 
A
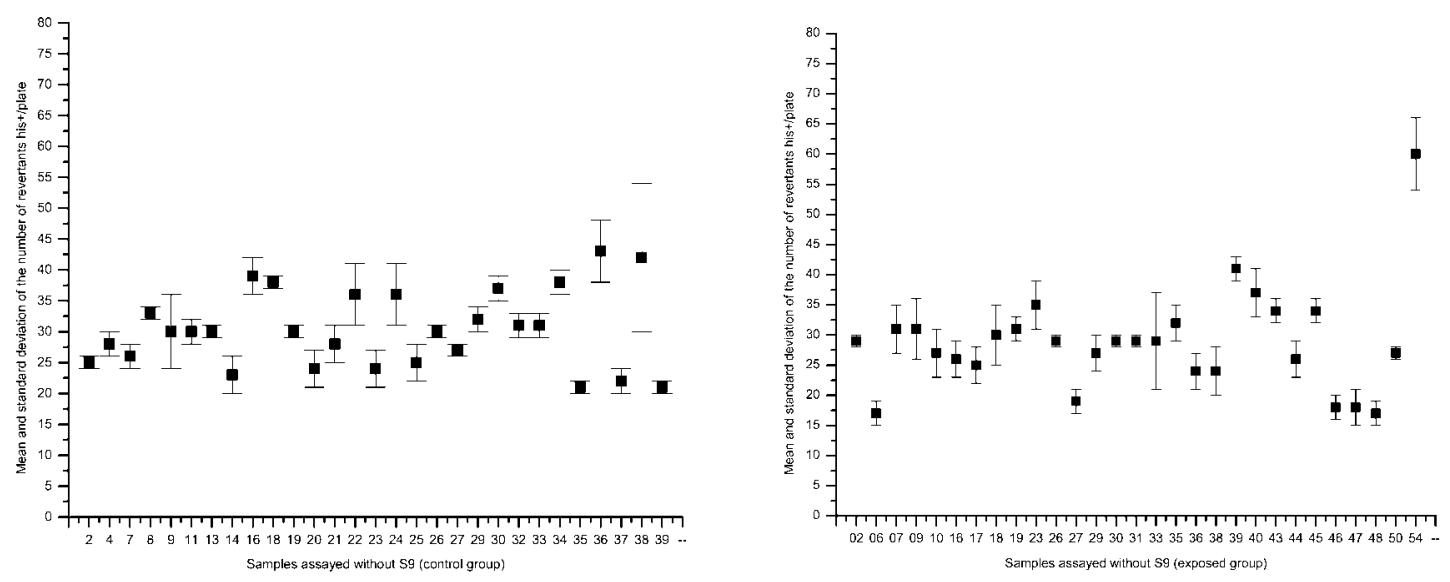

B
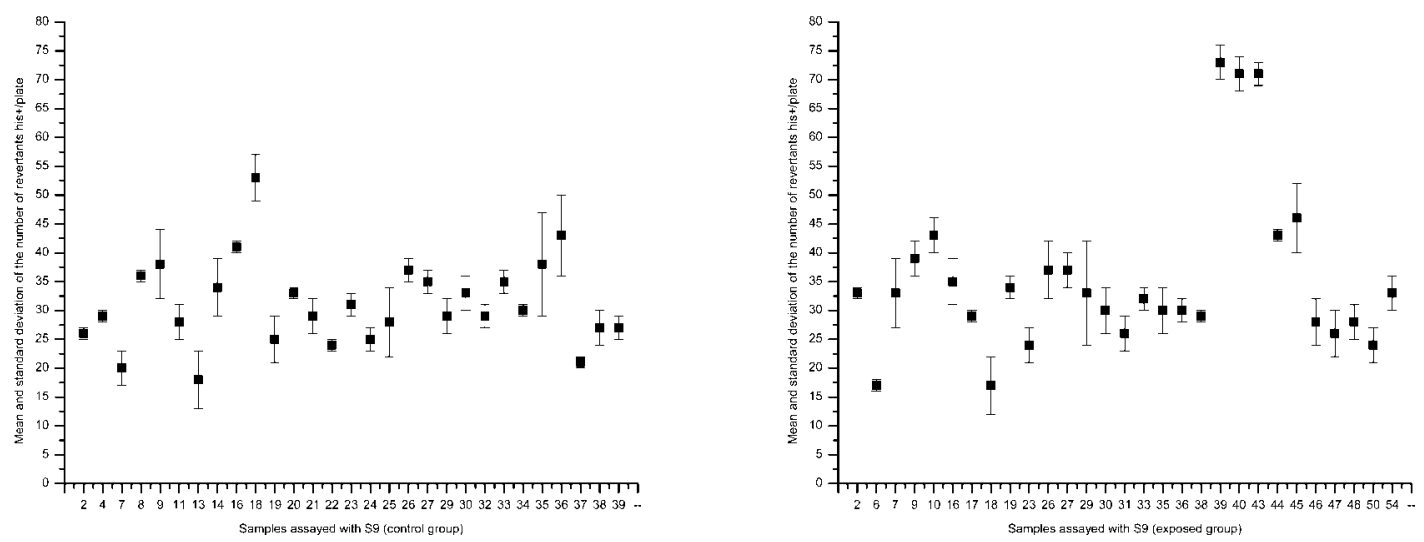

Fig. 2. Mean and standard deviation of the number of his+ revertants/plate for urine samples (12.0 $\mathrm{m} l$ equivalent of urine) from individuals from the control and exposed groups in the Salmonella typhimurium YG1024 strain, without (A) and with (B) metabolic activation.

strain, YG1024, in the presence of S9 mix. Although this finding is in general agreement with previous observations $^{30,38,39)}$, it is difficult to rationalize with the presumed exposure to solvents for the exposed population in this study. Our results with strain YG1024 (+S9) suggest that the workers are exposed to indirect mutagens and the mutagenicity in these chemical workers may have been due to exposure to solvents.

Our results indicate that YG1024 a Salmonella typhimurium derivative with high activity of Oacetyltransferase, is a suitable indicator strain for a urine mutagenicity test. This strain is highly sensitive to the mutagenicity of nitro, amino and hydroxylamino aromatics ${ }^{20)}$. A complication in the urine mutagenicity test is the effect of smoking, but in our samples smokers were excluded.

The highest increase of mutagenicity was observed with YG1024, in the presence of S9 mix, and this suggests that sulfo-conjugated aromatic amines were present in the urine of exposed workers. Benzene is metabolized to phenol, dihydroxybenzene, benzoquinone, transmuconic aldehyde and catechol ${ }^{5}$. The strain YG1024 shows evidence of the presence of amino aromatic derivatives which might be responsible for bladder cancer ${ }^{20)}$. Researches have shown that workers employed in footwear manufacture are at increased risk of some cancers, the strongest evidence being for nasal cancer and leukemia. Footwear workers are routinely exposed to complex mixtures of solvents, such as toluene, nhexane and acetone. Comet assay results showed that there was a significant increase in the mean damage index for the group exposed to solvents in comparison to the control group ${ }^{40}$. Although, Choi et al $^{41)}$ showed a positive Ames test associated significantly with current occupation 
Table 2. Highest mutagenic index (MI) detected with S.typhimurium strains TA100 and YG1024 for urine samples from the exposed group (E) and control group (C), with (+S9) and without (-S9) metabolic activation

\begin{tabular}{|c|c|c|c|c|c|c|c|c|c|}
\hline \multirow[b]{3}{*}{ Code } & \multicolumn{4}{|c|}{ Control group } & \multirow[b]{3}{*}{ Code } & \multicolumn{4}{|c|}{ Exposed group } \\
\hline & \multicolumn{2}{|c|}{ TA100 } & \multicolumn{2}{|c|}{ YG1024 } & & \multicolumn{2}{|c|}{ TA100 } & \multicolumn{2}{|c|}{ YG1024 } \\
\hline & $-\mathrm{S} 9$ & $+\mathrm{S} 9$ & $-\mathrm{S} 9$ & $+\mathrm{S} 9$ & & $-\mathrm{S} 9$ & $+\mathrm{S} 9$ & $-\mathrm{S} 9$ & $+\mathrm{S} 9$ \\
\hline $02 \mathrm{C}$ & 1.0 & 1.1 & 1.3 & 1.2 & $02 \mathrm{E}$ & 1.1 & 1.2 & 1.0 & 2.3 \\
\hline $04 \mathrm{C}$ & 2.2 & 1.5 & 1.5 & 1.4 & $06 \mathrm{E}$ & 1.1 & 1.4 & 1.2 & 1.4 \\
\hline $07 \mathrm{C}$ & 1.2 & 1.2 & 1.2 & 1.1 & 07E & 1.2 & 1.1 & 1.1 & 1.6 \\
\hline $08 \mathrm{C}$ & 1.0 & 1.2 & 1.2 & 1.4 & 09E & 0.8 & 1.1 & 1.1 & 2.2 \\
\hline 09C & 0.8 & 1.2 & 1.1 & 1.8 & $10 \mathrm{E}$ & 1.0 & 1.1 & 1.0 & 1.9 \\
\hline $11 \mathrm{C}$ & 1.1 & 1.3 & 1.0 & 1.5 & $16 \mathrm{E}$ & 1.2 & 1.1 & 1.2 & 1.7 \\
\hline $13 \mathrm{C}$ & 1.1 & 1.2 & 1.0 & 1.6 & $17 \mathrm{E}$ & 1.5 & 1.3 & 0.9 & 1.2 \\
\hline $14 \mathrm{C}$ & 1.1 & 1.0 & 1.0 & 1.2 & $18 \mathrm{E}$ & 1.3 & 1.0 & 1.2 & 1.0 \\
\hline $16 \mathrm{C}$ & 1.1 & 1.1 & 1.0 & 1.4 & $19 \mathrm{E}$ & 1.1 & 1.1 & 1.1 & 1.6 \\
\hline $18 \mathrm{C}$ & 1.1 & 1.0 & 1.5 & 1.4 & $23 \mathrm{E}$ & 1.8 & 1.2 & 1.6 & 1.4 \\
\hline $19 \mathrm{C}$ & 1.0 & 1.0 & 1.1 & 1.0 & $26 \mathrm{E}$ & 1.0 & 1.1 & 1.4 & 1.8 \\
\hline $20 \mathrm{C}$ & 1.2 & 1.1 & 0.9 & 1.4 & $27 \mathrm{E}$ & 1.1 & 1.6 & 1.5 & 1.7 \\
\hline $21 \mathrm{C}$ & 1.5 & 1.2 & 1.2 & 1.2 & $29 \mathrm{E}$ & 1.1 & 1.3 & 1.2 & 1.3 \\
\hline $22 \mathrm{C}$ & 1.5 & 1.2 & 1.3 & 1.0 & $30 \mathrm{E}$ & 1.0 & 1.1 & 1.5 & 1.5 \\
\hline $23 \mathrm{C}$ & 1.5 & 1.1 & 0.9 & 1.2 & $31 \mathrm{E}$ & 1.0 & 1.6 & 1.4 & 1.4 \\
\hline $24 \mathrm{C}$ & 1.3 & 1.2 & 1.3 & 1.0 & $33 \mathrm{E}$ & 1.1 & 1.1 & 1.4 & 1.5 \\
\hline $25 \mathrm{C}$ & 1.1 & 1.2 & 1.0 & 1.2 & $35 \mathrm{E}$ & 1.2 & 1.3 & 1.3 & 1.4 \\
\hline $26 \mathrm{C}$ & 1.1 & 1.8 & 1.4 & 1.7 & $36 \mathrm{E}$ & 1.1 & 1.9 & 1.2 & 1.7 \\
\hline $27 \mathrm{C}$ & 1.1 & 1.4 & 1.4 & 1.6 & $38 \mathrm{E}$ & 1.5 & 1.1 & 1.6 & 1.4 \\
\hline $29 \mathrm{C}$ & 1.0 & 1.1 & 1.4 & 1.4 & $39 \mathrm{E}$ & 1.5 & 1.1 & 1.4 & 3.3 \\
\hline $30 \mathrm{C}$ & 1.4 & 1.1 & 1.3 & 1.8 & $40 \mathrm{E}$ & 1.2 & 1.4 & 1.8 & 2.6 \\
\hline $32 \mathrm{C}$ & 0.9 & 1.2 & 1.1 & 1.4 & $43 \mathrm{E}$ & 1.2 & 1.3 & 1.0 & 1.3 \\
\hline $33 \mathrm{C}$ & 1.2 & 1.1 & 1.2 & 1.7 & $44 \mathrm{E}$ & 1.3 & 1.6 & 1.0 & 2.0 \\
\hline $34 \mathrm{C}$ & 1.2 & 1.0 & 1.4 & 1.4 & $45 \mathrm{E}$ & 1.3 & 1.3 & 1.5 & 2.1 \\
\hline $35 \mathrm{C}$ & 1.3 & 1.6 & 1.2 & 1.2 & $46 \mathrm{E}$ & 1.9 & 1.4 & 1.0 & 1.6 \\
\hline $36 \mathrm{C}$ & 1.0 & 1.2 & 2.0 & 1.4 & $47 \mathrm{E}$ & 1.4 & 1.4 & 1.2 & 1.4 \\
\hline $37 \mathrm{C}$ & 1.2 & 1.1 & 1.2 & 1.3 & $48 \mathrm{E}$ & 1.1 & 1.1 & 1.1 & 1.6 \\
\hline $38 \mathrm{C}$ & 1.1 & 1.1 & 1.9 & 1.0 & $50 \mathrm{E}$ & 1.2 & 1.1 & 1.3 & 1.4 \\
\hline $39 \mathrm{C}$ & 1.1 & 1.0 & 1.2 & 1.4 & $54 \mathrm{E}$ & 1.1 & 1.3 & 2.2 & 1.2 \\
\hline M & 1.2 & 1.2 & 1.3 & 1.4 & M & 1.2 & 1.3 & 1.3 & $1.7 *$ \\
\hline
\end{tabular}

The values in boldface represent $\mathrm{MI} \geq 2$.0. The statistical significance of the different groups was calculated using $t$-test; the level of significance was taken as $p \leq 0.05$. Most of the values was obtained for the dose of $12 \mathrm{~m} l$ equivalent of urine (11C, 13C, 20C, 30C, 35C, 36C, 37C, 39C and 6E, 9E, 19E, 26E, 29E, 39E, 43E, 50E for $6 \mathrm{ml}$; 16C, 21C, 22C, 38C and $2 \mathrm{E}, 7 \mathrm{E}, 16 \mathrm{E}, 17 \mathrm{E}$ for $3 \mathrm{ml}$ equivalent of urine).

Table 3. Mutagenic activity expressed as potency (number of revertants/ml equivalent of urine samples from control and exposed groups), with positive mutagenic activity, assayed in strains TA100 and YG1024 with (+S9) or without (-S9) metabolic activation

\begin{tabular}{|c|c|c|c|c|c|c|c|c|c|}
\hline \multirow[b]{3}{*}{ Code } & \multicolumn{4}{|c|}{ Control group } & \multirow[b]{3}{*}{ Code } & \multicolumn{4}{|c|}{ Exposed group } \\
\hline & \multicolumn{2}{|c|}{ TA100 } & \multicolumn{2}{|c|}{ YG1024 } & & \multicolumn{2}{|c|}{ TA100 } & \multicolumn{2}{|c|}{ YG1024 } \\
\hline & $-\mathrm{S} 9$ & $+\mathrm{S} 9$ & $-\mathrm{S} 9$ & $+\mathrm{S} 9$ & & $-\mathrm{S} 9$ & $+\mathrm{S} 9$ & $-\mathrm{S} 9$ & $+\mathrm{S} 9$ \\
\hline $04 \mathrm{C}$ & 2.3 & 0 & 0 & 0 & $02 \mathrm{E}$ & 0 & 0 & 0 & 9.2 \\
\hline \multirow[t]{6}{*}{$36 \mathrm{C}$} & 0 & 0 & 13.8 & 0 & 09E & 0 & 0 & 0 & 12.9 \\
\hline & & & & & $39 \mathrm{E}$ & 0 & 0 & 0 & 25.1 \\
\hline & & & & & $40 \mathrm{E}$ & 0 & 0 & 0 & 10.4 \\
\hline & & & & & $44 \mathrm{E}$ & 0 & 0 & 0 & 1.8 \\
\hline & & & & & $45 \mathrm{E}$ & 0 & 0 & 0 & 4.2 \\
\hline & & & & & $54 \mathrm{E}$ & 0 & 0 & 2.6 & 0 \\
\hline
\end{tabular}


A

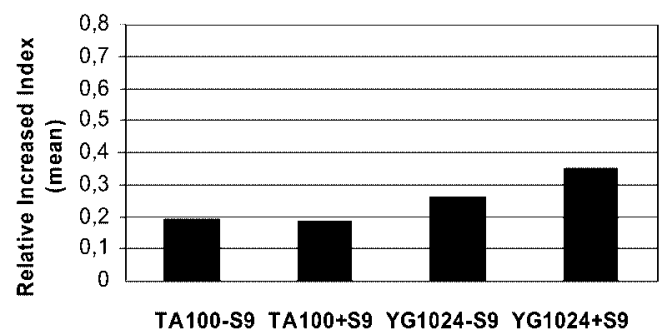

B

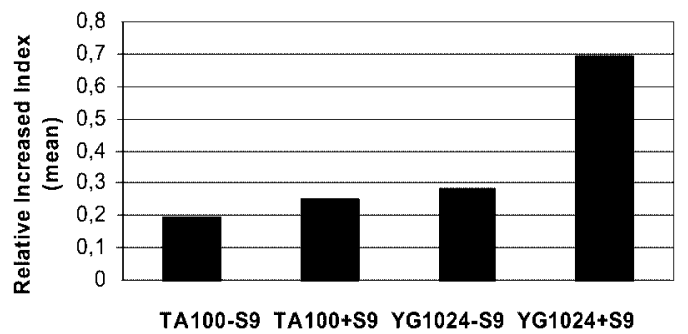

Fig. 3. Mean of relative increase index in the number of his+ revertants of urine samples from individuals of the control (A) and exposed (B) group.

hazard (such as solvents), no significant association was found with bladder cancer. There are numerous case reports of various forms of leukemia, following protracted exposure to benzene. However, this evidence of possible causation was considered only suggestive and bioassays of benzene for carcinogenicity to animals were considered inconclusive ${ }^{42}$. Benzene is an aromatic solvent and was included in this study. Certain benzene metabolites are genotoxic and mutagenic. It is believed that benzene exerts its adverse effects by metabolic activation of toxic metabolites ${ }^{43)}$.

In conclusion, several strains of S.typhimurium should be used to assess the mutagenic effect, and our study showed an increase in urinary mutagenic activity in chemistry laboratory workers using the strain YG1024 $(+S 9)$. The results in this paper represent an initial step in our effort to understand the genetic susceptibility to DNA damage of laboratory chemical workers and are of potential importance in the reduction of disease risk for these workers.

Acknowledgment: We are grateful to the volunteers from the Chemical Institute (UNESP-Araraquara). This research was supported by CAPES (the Brazilian Coordinating Committee for Postgraduate Courses).

\section{References}

1) Phillips BJ and Jenkinson P: Is ethanol genotoxic? A review of the published data. Mutagenesis 16, 91-101 (2001)

2) Joo WA, Donggeun S, Lee DY, Lee E and Kim CW: Proteomic analysis of plasma proteins of workers exposed to benzene. Mutat Res 558, 35-44 (2004)

3) Snyder R, Lee EW, Kocsis JJ and Witmer CM: Bone marrow depressant and leukemogenic actions of benzene. Life Sci 21, 1709-1722 (1977)

4) Akson M: Benzene as leukemogenic and carcinogenic agent. Am J Ind Med 8, 9-20 (1985)

5) Andrews LS and Snyder R: Toxic effects of solvents and vapors. In: Amdur MO, Doull J, Klaassen CD, eds.Toxicology-The Basic Science of Poisons. New
York: Pergamon Press, 1991: 681-722.

6) Fechner G, Ortmann A and Köhler H: Fatal intoxication due to excessive dichloromethane inhalation. Forensic Science International 22, 69-72 (2001)

7) Maninni P, Andreoli R and Niessen WMA: Liquid chromatography-mass spectrometry in occupational toxicology: a novel approach to the study of biotransformation of industrial chemicals. J Chromatography A 1058, 21-37 (2004)

8) Neubert D, Gericke C, Hanke B, Beckmann G, Baltes MM, Kuhl K-P, Bochert G, Hartmann J and Toluene Field Study Group: Multicenter field trial on possible health effects of toluene II. Cross sectional evaluation of acute low-level exposure. Toxicology 168, 159-183 (2001)

9) DeFlora S, Zanacchi P, Camoirano A, Bennocelli C and Badolati GS: Genotoxic activity of 135 compounds in the Ames revertion test and in bacterial DNA-repair test. Mutat Res 133, 161-198 (1984)

10) Andre V, Lebailly P, Deslands E, Henry-Amar M and Gauduchon P: Biomonitoring of urine mutagenicity with the Ames test: improvement of the extraction/ concentration method. Mutat Res 520, 199-205 (2002)

11) DeMarine DM, Brooks LR, Bhatanagar VK, Hayes RB, Eischein BT, Shelton ML, Zenser TV, Talaska G, Kashyap R, Parikh DJ, Lakshmi V, Hsu F, Davis BB, Jarger $\mathrm{M}$ and Rothman N: Urinary mutagenicity as a biomarker in workers exposed to benzidine: correlation with urinary metabolites and urothelial DNA adducts. Carcinogenesis 18, 981-988 (1997)

12) Yamasaki E and Ames BN: Concentration of mutagens from urine by adsorption with the nonpolar resin XAD2: cigarrete smokers have mutagenic urine. Proc Natl Acad Sci 74, 3555-3559 (1977)

13) Falck P, Gröhn M, Sorsa H, Vainio E, Heinonen K and Holsti LR: Mutagenicity in urine of nurses handling cytostatic drugs. Lancet 1, 1250-1251 (1979)

14) Doolittle DJ, Rahn CA, Burger JT, Lee CK, Reed B, Riccio E, Howard G, Passananti GT, Vesell ES and Hayes AW: Effect of cooking methods on the mutagenicity of food and on urinary mutagenicity of human consumers. Food Chem Toxicol 27, 657-666 (1989) 
15) Falck K, Sorsa M, Vainio H and Kilpikari I: Mutagenicity in urine of workers in rubber industry. Mutat Res 79, 445-452 (1980)

16) Sinues B, Perez J, Bernal ML, Saenz MA, Lanuza J and Bartolome M: Urinary mutagenicity and $\mathrm{N}$-acetylation phenotype in textile industry workers exposed to arylamines. Cancer Res 52, 4885-4889 (1992)

17) Dolara P, Mazzoli S, Rosi D, Buiatti E, Baccetti S, Turchi A and Vannucci V: Exposure to carcinogenic chemicals and smoking increases urinary excretion of mutagens in humans. Toxicol Environ Health 8, 95103 (1981)

18) Maron DM and Ames BN: Revised methods for the Salmonella mutagenicity test. Mutat Res 113, 173-225 (1983)

19) Watanabe M, Ishidate MJ and Nohemi T: Sensitive method for detection of mutagenic nitroarenes and aromatic amines: new derivates of Salmonella typhimurium tester strains possessing elevated O-acetiltransferase levels. Mutat Res 234, 337-348 (1990)

20) Einistö P, Noehmi T and Ishidate M: Sentivivity of Salmonella typhimurium YG1024 urine mutagenicity caused by cigarrete smoking. Mutat Res 245, 87-92 (1990)

21) Varella SD, Pozetti GL, Vilegas W and Varanda EA: Mutagenic activity of sweepings and pigments of a household-wax factory assayed with Salmonella typhimurium. Food Chem Toxicol 42, 2029-2035 (2004)

22) Marques RCP, Medeiros SRB, Dias CS, Barbosa-Filho JM and Agnez-Lima LF: Evaluation of the mutagenic potential of yangambin and of the hydroalcoholic extract of Ocotea duckei by the Ames Test. Mutat Res 536, 117-120 (2003)

23) Cavalcanti AAM, Rubensam G, Picada JN, Silva EG, Moreira JCF and Henriques JAP: Mutagenicity, antioxidant potential, and antimutagenic activity against hydrogen peroxide of cashew (Anacardium occidentale) apple juice and cajuína. Environ and Mol Mutagen 41, 360-369 (2003)

24) Kutlu M, Aydogan G, Susuz F and Özata A: The Salmonella mutagenicity of water and sediments from the Porsuk River in Turkey. Environ Toxicol and Pharmacol 17, 111-116 (2004)

25) Hakura A, Shimada H, Nakajima M, Sui H, Kitamoto S, Suzuki S and Satoh T: Salmonella/human S9 mutagenicity test: a collaborative study with 58 compounds. Mutagenesis 20, 217-228 (2005)

26) Mortelmans K and Zeiger E: The Ames Salmonella/ microsome mutagenicity assay. Mutat Res 455, 29-60 (2000)

27) Bernstein L, Kaldor J, McCann J and Pike MC: An empirical approach to the statistical analysis of mutagenesis dad from the Salmonella test. Mutat Res 97, 267-281 (1982)

28) Hansen AM, Wallin H, Binderuo ML, Dybdahl M, Autrup H, Loft $S$ and Knudsen LE: Urinary 1hydroxypyrene and mutagenicity in bus drivers and mail carriers exposed to urban air pollution in Denmark. Mutat Res 557, 7-17 (2004)

29) Simioli P, Lupi S, Gregório P, Siwinska E, Mielzynska D, Clonfero E and Pavanello S: Non-smoking coke oven workers show an occupational PAH exposurerelated increased in urinary mutagens. Mutat Res 562, 103-110 (2004)

30) Vermeulen R, Bos RP, Pertijs J and Kromhout H: Exposure related mutagens in urine of rubber workers associated with inhalable particulate and dermal exposure. Ocupp Environ Med 60, 97-103 (2003)

31) Hayes $S:$ RK bacterial test for independently measuring chemical toxicity and mutagenicity: short-term forward selection assay. Mutat Res 130, 97-106 (1984)

32) Hellmer L and Bolcsfoldi G: An evaluation of the $E$. coli $\mathrm{K}-12 \mathrm{uvrB} / \mathrm{rec} A \mathrm{DNA}$ repair host mediated assay. Mutat Res 272, 145-160 (1992)

33) Zeiger E, Anderson B, Haworth S, Lawler T and Mortelmans K: Salmonella mutagenicity tests: V. Results from the testing of 311 chemicals. Environ Mol Mutagen 19, 2-141 (1992)

34) Uuksulainen SO, Heikkilä PR, Olkinuora PS and Kiilunen M: Self-reported occupational health-hazards and measured exposures to airborne impurities and noise in shoe repair work. Int J Occup Environ Health 8, 320-327 (2002)

35) MacGregor D: The genetic toxicology of toluene. Mutat Res 317, 213-228 (1994)

36) Barry JP and Jenkinson P: Is ethanol genotoxic? A review of the published data. Mutagenesis 16, 91-101 (2001)

37) Cerná M, Pastorková A, Myers RS, Rössner P and Binková B: The use of a urine mutagenicity assay in the monitoring of environmental exposure to genotoxins. Mutat Res 391, 99-101 (1997)

38) Smith CJ, Bombick DW, Ryan BA, Morgan WT and Doolittle DJ: Urinary mutagenicity in nonsmokers follwing exposure to fresh diluted sidestream cigarette smoke. Mutat Res 470, 53-70 (2000)

39) Gabbani G, Pavanello S, Nardini B, Tognato O, Bordin A, Fornasa CV, Bezze $\mathrm{G}$ and Clonfero E: Influence of metabolic genotype GSTM1 on levels of urinary mutagens in patients treated topically with coal tar. Mutat Res 440, 27-33 (1999)

40) Heuser VD, Andrade VM, Silva J and Erdtman B: Comparison of genetic damage in brazilian footwearworkers exposed to solvent-based or water-based adhesive. Mutat Res 583, 85-94 (2005)

41) Choi BCK, Connolly JG and Zhou RH: Application of urinary mutagen testing to detect workplace hazardous exposure and bladder cancer. Mutat Res 341, 207-216 (1995)

42) Bird MG, Greim H, Snyder R and Rice JM: International symposium: recent advances in benzene toxicity. Chem Biol Interact 153-154, 1-5 (2005)

43) Khan HA: Benzene's toxicity: a consolidated short review of human and animal studies. Hum Exp Toxicol 26, 677-685 (2007) 